\title{
Round table on morbilliviruses in marine mammals
}

\author{
T. Barrett ${ }^{a}$, M. Blixenkrone-Møller ${ }^{b}$, M. Domingo ${ }^{c}$, T. Harder ${ }^{d}$, P. Have ${ }^{c}$, B. \\ Liess $^{\text {d }}$, C. Örvell ${ }^{\mathrm{f}}$, A.D.M.E. Osterhaus ${ }^{\mathrm{g}}$, J. Plana ${ }^{\mathrm{h}}$ and V. Svansson ${ }^{\mathrm{b}}$ \\ a Pirbright Laboratory, Pirbright, Woking, liK \\ 'Dept. of Veterinary Microbiology, The Royal Veterinary and Agricultural University, Frederiksherg. \\ Denmark \\ 'Dept. of Veterinary Pathology, Universidad Autònoma de Barcelona, Barcelona, Spain \\ 'Institute of Virology, Hannover Veterinary School, Hannover, Germany' \\ 'State Veterinary Institute for Virus Reseach, Kalvehave, Denmark \\ ${ }^{\mathrm{f}}$ National Bacteriological Laboratory, Karolinska Institute, Stockholm, Sweden \\ ${ }^{B}$ National Institute of Public Health and Environmental Protection, Bilthoven. Netherlands \\ 'Laboratorios Sobrino SA, Vall de Bianca, Gerona, Spain
}

(Accepted 26 June 1992)

\begin{abstract}
Barrett, T., Blixenkrone-Møller, M., Domingo, M., Harder, T., Have, P., Liess, B., Örvell, C., Osterhaus, A.D.M.E., Plana, J. and Svansson, V., 1992. Round table on morbilliviruses in marine mammals. Vet. Microbiol., 33: 287-295.

Since 1988 morbilliviruses have been increasingly recognized and held responsible for mass mortality amongst harbour seals (Phoca vitulina) and other seal species. Virus isolations and characterization proved that morbilliviruses from seals in Northwest Europe were genetically distinct from other known members of this group including canine distemper virus (CDV), rinderpest virus, peste des petits ruminants virus and measles virus. An epidemic in Baikal seals in 1987 was apparently caused by a morbillivirus closely related to CDV so that two morbilliviruses have now been identified in two geographically distant seal populations, with only the group of isolates from Northwest Europe forming a new member of the genus morbillivirus: phocid distemper virus (PDV). Because of distemperlike disease, the Baikal seal morbillivirus was tentatively named PDV-2 in spite of its possible identity with CDV. The appearance of morbilliviruses in the Mediterranean Sea causing high mortality amongst dolphins should further increase the research activities on protection strategies for endangered species of marine mammals.
\end{abstract}

\section{INTRODUCTION}

Until recently morbilliviruses were thought to occur only in terrestrial mammals where their severe effects have been known since antiquity. The

Correspondence to: Prof. Dr. B. Liess, Institute of Virology, Hannover Veterinary School, Bischofholer Damm 15, D-3000 Hannover, Germany. 
recognition of morbilliviruses as a cause of mass mortality amongst pinniped species in Northwestern Europe and Siberia, and the recent occurrence amongst cetaceans in the Mediterranean Sea emphasizes the importance of this virus group in marine mammals and has opened a new field of interest to virologists. Immediately several research groups devoted considerable efforts trying to elucidate aspects of morbillivirus infection in seals, porpoises and dolphins, such as the origin of the virus, and the relationship between marine mammal isolates and the known morbilliviruses causing rinderpest in ruminants, distemper in carnivores or measles in man. There was tremendous public interest at the beginning of the "seal plague" and this will probably increase again if the threat to populations of endangered species is further highlighted. Although public interest might be a stimulating factor, a scientific rather than emotional approach is essential in addressing the problems posed by investigation of disease in marine wildlife. Studies on marine mammals are hampered by their natural environment which is generally inaccessible to veterinary virologists. Attempts to elucidate the aetiology, pathogenesis and epidemiology, and formulate possible control measures require close cooperation with other biologists. The round table held at the Second Congress of the ESVV in Uppsala provided an appropriate forum to crystallize the problems surrounding virus infections in marine mammals.

\section{IDENTIFICATION AND TAXONOMY OF PHOCID DISTEMPER VIRUS}

A morbillivirus related to canine distemper virus (CDV) was identified as the presumed cause of an epizootic in harbour (common) and grey seals in Northern European waters in the summer and autumn of 1988 (Kennedy et al., 1988; Osterhaus and Vedder, 1988). Hybridization analysis using cDNA probes derived from the nucleocapsid genes of rinderpest virus (RPV), peste des petits ruminants virus, measles virus (MV) and CDV indicated the presence in diseased seal tissues of a morbillivirus which was different from any previously known members of the genus (Mahy et al., 1988; Bostock et al., 1990). The seal virus bound CDV-specific but not MV-specific monoclonal antibodies (Cosby et al., 1988). Immunofluorescence shown by staining of MDCK cell monolayers with morbillivirus-specific monoclonal antibodies after inoculation of virus passaged in SPF dogs was blocked by a hyperimmune anti-CDV SPF dog serum (Osterhaus et al., 1988). Marked differences were detected in the virus-induced proteins of the proposed phocine distemper virus (PDV) as compared with other morbilliviruses, by immunoprecipitation of radiolabelled antigens with monoclonal antibodies (Rima et al., 1990).

Direct virus isolation in seal kidney cell cultures and detection by typical cytopathic effects and peroxidase-linked antibody (PLA) assay allowed comparative studies with sera collected from seals (Liess et al., 1989a; Zaghawa 
et al., 1990). Presence of antibodies was assessed by a direct neutralizing peroxidase-linked antibody (NPLA) assay using a phocine morbillivirus isolate and CDV strain "Rockborn", respectively. Sera collected from seals during the 1988 epizootic showed a ten- to 30 -fold greater neutralization of PDV than of CDV strain "Rockborn" (Liess et al., 1989b,c).

Further evidence that PDV is distinct from CDV resulted from genetic studies on PDV RNA, extracted from seal tissues or from infected tissue culture cells using slot hybridization and the polymerase chain reaction (PCR) amplification assay (Mahy et al., 1988; Curran et al., 1990; Haas et al., 1991). More recently the nucleotide and deduced amino acid sequences were determined for five PDV genes named, in analogy to the encoded structural proteins of other morbilliviruses: nucleoprotein $(N)$, phosphoprotein $(P)$, matrix (M), fusion protein (F) and haemagglutinin (H). The PDV genome exhibited characteristics typical of morbillivirus. The $P$ gene followed the motif of measles virus (MV) with distinct coding capacity for three proteins: P, V and C (Blixenkrone-Møller et al., 1992). Like the other morbilliviruses, the $\mathrm{P}$ gene of PDV encodes two additional non-structural proteins, $\mathrm{C}$ and $\mathrm{V}$, in alternative reading frames. The $\mathrm{C}$ and $\mathrm{V}$ protein show much greater conservation compared with $C D V$ than do the corresponding $P$ protein regions. This probably indicates that there is much stronger selective pressure to preserve the sequence of the non-structural proteins (Barrett et al., 1992). The close relationship between PDV and CDV was demonstrated by comparison of genomic data, as reflected in the amino acid sequence, with other morbilliviruses. The genus could be subdivided into the distemper group (CDV and PDV) and the rinderpest-measles group (RPV and MV). The deduced amino acid sequence homologies between the glycoproteins of PDV and CDV were $74 \%(\mathrm{H})$ and $84 \%(\mathrm{~F})$ (Kövamees et al., 1991). The differences found between PDV and CDV at the genomic level indicated that these are two separate viruses.

Immunological investigations using monoclonal antibodies (mAbs) against $H$ protein also revealed a close relationship between phocine and canine distemper virus but did not distinguish PDV from a morbillivirus isolated from mink (Örvell et al., 1990). In contrast, using mAbs against PDV strain 2558/ Han88, an analysis of antigenic differences between a number of PDV isolates and other morbilliviruses showed that a field isolate from a ferret was clearly distinguishable from PDV (Harder et al., 1991). Recent studies indicated that PDV can also infect terrestrial carnivores and caused field outbreaks of distemper in farmed mink in Denmark in 1989. This led to the question whether PDV forms a threat to terrestrial mammals (BlixenkroneMøller et al., 1990).

A disease of high mortality in Baikal seals (Phoca sibirica) was also apparently caused by a morbillivirus closely related, or even identical, to canine distemper virus (Grachev et al., 1989). Although indistinguishable from CDV, this virus was called PDV-2 based on its phocid origin and because of its 
dissimilarity to the seal virus of Northwestern Europe (now termed PDV-1) (Visser et al., 1990). In view of the close identity between PDV-2 and CDV, its taxonomic position remains uncertain, and only PDV-1 is considered to be a newly recognized member of the genus Morbillivirus (Osterhaus et al., 1990).

\section{PATHOGENESIS OF MORBILLIVIRUS IN SEALS}

In an attempt to elucidate some of the routes of CDV infection, young harbour seals (Phoca vitulina) were inoculated with a CDV strain that was virulent for dog and mink. The inoculated seals showed clinical signs which were somewhat similar to those observed in distemper in dogs and mink. Viral replication in lymphoid tissues was followed by pronounced immunosuppression. Spread to non-lymphoid tissues could not be detected. No transmission to contact seals or mink could be demonstrated. These results indicated that harbour seals are probably not highly sensitive to infection with CDV. In contrast, morbillivirus derived from diseased harbour seals produced signs of acute canine distemper in mink resembling the acute systemic and nervous form of the infection (Blixenkrone-Møller et al., 1989).

In SPF beagle puppies PDV strain $2558 / \mathrm{Han} 88$ proved to be non-pathogenic with no clinical signs or temperature rise during a 13-week observation period. Neutralizing antibody titres against the homologous virus developed after primary inoculation with PDV and were consistently higher than against CDV strain "Rockborn" even after challenge 3 months later (Jäger et al., 1990).

Transmission experiments using the same, low dose of strain $2558 / \mathrm{Han} 88$ in eight harbour seals (Phoca vitulina), two of them seronegative, six seropositive to the homologous PDV strain, resulted in clinical signs in the two seronegatives, resembling those seen in the 1988 seal disease epidemic. One of the seals succumbed to the infection while the seropositive animals were protected from clinical disease. A seropositive grey seal (Halichoerus grypus) inoculated intranasally with the same dose and strain of PDV did not develop any signs of disease (Harder et al., 1990). This transmission trial agrees with observations in British waters where grey seals are more common than harbour seals and where the latter were predominantly affected with the disease (Carter et al., 1989). It is well known from other morbillivirus infections that not only are pathogenicity and virulence of the virus important factors, but that host species and even breed might account for differences in the course of the disease, as seen in rinderpest and canine distemper (reviewed by Appel et al., 1981).

In the public view, environmental pollution-among other factors-was thought to play an important role in the development of mass mortality of seals in 1989. Uncertainty remains, especially concerning the role of poly- 
chlorinated biphenyls (PCB), because of their immunosuppressive potential in laboratory animals. In order to assess the significance of PCBs in PDV infections of seals, clinically healthy harbour seals were orally exposed for several weeks to a mixture of PCB-congeneres found in fish from the North Sea, then inoculated with culture-adapted PDV strain 2558/Han 88.

Ten PDV-seronegative subadult harbour seals developed severe signs of "seal plague" within 7 days post inoculation (p.i.). Six of the seals died from the infection within 11 to 16 days p.i. Systemic infection and spread of the inoculated virus were confirmed by the presence of cell-associated viraemia, detection of antigen in tissues of fatally infected seals by use of PDV-induced monoclonal antibodies as well as detection of PDV-RNA in peripheral mononuclear blood cells and various tissues by PCR/Southern blotting. A specific humoral immune response was demonstrated in the survivors.

With regard to the clinical course, including mortality rates, duration of viraemia, antigen distribution in tissues and humoral immune response in convalescent seals, no significant differences were detectable between the groups of PCB-conditioned and unconditioned seals. Although the amount of PCBs accumulating in conditioned seals was considerably lower than that found in free-ranging seals of the same age-group, the development and course of the disease in unconditioned animals provided evidence that PCBs are not an important aggravating factor in PDV infections of harbour seals (Harder et al., 1992).

\section{EPIZOOTIOLOGY}

The existence of an epizootiological link between mass mortality in Lake Baikal seals a year earlier, and the PDV infections in other pinniped species in Northwestern Europe remained questionable (reviewed by Osterhaus et al., 1990). Although detection of CDV-neutralizing antibodies has been reported among seals in Europe, Siberia, Greenland and the Antarctic, no firm conclusions can be drawn as to the origin of infections (Dietz et al., 1989; Have et al., 1989; Osterhaus et al., 1989; Bengtson et al., 1991).

After the identification of phocid morbilliviruses (PDV-1 and PDV-2) as the primary cause of serious outbreaks of distemper among seals in Northwestern Europe in 1988 and in Siberia in 1987, the presence of morbilliviruses was demonstrated in several other marine mammal species. A worldwide serological survey indicated that morbillivirus infections are indeed quite common in pinnipeds and cetaceans. Among aquatic mammals morbilliviruses have also been isolated from porpoises (Kennedy et al., 1988) and more recently from striped dolphins in the Mediterranean Sea showing that the epizootiology of morbillivirus infections in marine mammals involves not just pinnipeds but cetaceans too (Domingo et al., 1990). 
In the summer of 1990 an epidemic affected a population of striped dolphins (Stenella coeruleoalba) in the Spanish Mediterranean Sea killing 400 of them. The epizootic extended to the French and Western Italian coasts and to the Mediterranean coast of Africa. The viral agent was isolated in cell cultures from brain and lungs of moribund or dead dolphins. Infected cell cultures gave positive reactions with a polyclonal antiserum to CDV using immunoenzymatic techniques. The disease reappeared in 1991, with mortality lower on Spanish coasts, but high along the Italian coasts with 58 stranded dolphins being necropsied. Bronchiolo-interstitial pneumonia (72\%) and nonsuppurative encephalitis (69\%) were the most frequent histopathological lesions. Pneumonia was characterized by hyperplasia of alveolar epithelial type II cells and formation of multinucleate cells/syncytia in alveolar and bronchiolar lumina. Lymphoid depletion and formation of multinucleate cells/ syncytia in the cortex of lymph nodes were also prominent lesions. The distribution of morbillivirus-related antigen was investigated in 23 dolphins using a monoclonal antibody against the $\mathrm{H}$ glycoprotein of PDV. Positive immunostaining was found in brain $(77 \%)$, lung $(70 \%)$, and in mesenteric $(61 \%)$, mediastinal $(47 \%)$ and prescapular $(45 \%)$ lymph nodes. The relationship between the morbilliviruses isolated from dolphin, seal, and porpoise is under investigation (Domingo et al., 1992). To date at least two morbilliviruses have been isolated and characterized from cetacean species which proved to be quite distinct from the phocid distemper viruses, PDV-1 and PDV-2, on the basis of their antigen and other biological properties (Osterhaus et al., 1992).

\section{THE NEED FOR FURTHER RESEARCH}

The finding of morbilliviruses in marine mammals opened a new field of interest for veterinary virology and poses some intriguing questions:

(1) What is the origin of the various morbilliviruses found so far in marine mammals?

(2) How closely related to each other are the various morbilliviruses isolated from marine mammals?

(3) Why did a morbillivirus suddenly gain high virulence for some seal species, or was the devastating effect purely a result of virus introduction into a virgin population of a particular seal species?

(4) Is the PDV isolated from seals in Northwestern Europe solely responsible for mass mortality among seals, or does it need some extraneous co-factors?

(5) Can pinnipeds and other marine mammals in rehabilitation centres be protected against morbilliviruses by vaccination? 


\section{VACCINATION}

While some of the above questions can be answered only inadequately at present, indicating the need for continued collection of data from various parts of the world, including the Arctic and Antarctic, the final point demands urgent attention to ensure that pinnipeds and other wild marine mammals in rehabilitation centres develop a protective immune response following vaccination before their reintroduction to the wild.

A subunit morbillivirus vaccine based on the iscom matrix was shown to provide adequate protection against phocid distemper. The efficacy and safety of a candidate iscom CDV vaccine as well as a whole-virus CDV vaccine have been reported recently (Osterhaus et al., 1990). It would be interesting to know which proteins of CDV or PDV are responsible for the development of immunity in the mammals in question. The vaccines described by Osterhaus et al. (1990) induced CDV-neutralizing antibody titres of $1 / 300$ to $1 / 1000$ and the vaccinated seals were protected against challenge with organ suspension material that had produced a humoral immune response in 16 moribund seals. Rima et al. (1990) found the response to PDV, like CDV, restricted to nucleocapsid and phosphoproteins. Only a few sera precipitated the external glycoprotein antigens of both viruses. The frequent absence of antibodies to the viral glycoproteins in advanced stages of distemper encephalitis stresses the need for antibody response to the external proteins in vaccinated seals. Neutralizing antibodies did develop in seals inoculated with PDV no matter whether they survived or succumbed (Harder et al., 1992). As in canine distemper, neutralizing antibody titres up to $2.2 \log _{10} N_{50}$ were found in extracted organ tissues of dead seals. In convalescent seals maximum titres of $3.8 \log _{10} N_{50}$ were reached in the fourth week post inoculation. The figures suggest that, following vaccination, neutralizing titres must be well above $1 /$ 100 in order to correlate with immunity. However, further investigations are of paramount importance including the investigation of morbillivirus infections in a wide range of marine mammal species.

\section{REFERENCES}

Appel, M.J.G., Gibbs, E.P., Martin, S.J., Ter Meulen, V., Rima, B.K., Stephenson, J.R. and Taylor, W.P., 1981. Morbillivirus diseases of animals and man. In: E. Kurstak and C. Kurstak, Comparative Diagnosis of Viral Diseases, Vol. IV. Academic Press, New York, NY, pp. 235-297.

Barrett, T., Crowther, J., Osterhaus, A.D.M.E., Subbaro, S.M., Groen, I., Haas, L., Mamaev, L.V., Tirenko, A.M., Visser, I.K.G. and Bostock, C.J., 1992. Molecular and scrological studies on the recent seal virus epizootics in Europe and Siberia. Sci. Total Environ., 115: 117132.

Bengtson, I.L., Boveng, P., Franzen, U., Have, P., Heide-Sörgensen, M.P. and Härkönen, T.J., 1991. Antibodies to canine distemper in Antarctic seals. Mar. Mammal Sci., 7: 85-87. 
Blixenkrone-Moller, M., Svansson, V., Have, P., Bötner, A. and Nielsen, J., 1989. Infection studies in mink with seal-derived morbillivirus. Arch. Virol., 106: 165-170.

Blixenkrone-Møller, M., Svansson, V., Örvell, C. and Have, P., 1990. Phocine distemper virus-a threat to terrestrial mammals? Vet. Rec., 127: 263-264.

Blixenkrone-Møller, M., Sharma, B., Varsanyi, T.M., Norrby, E. and Kövamees, J., 1992. Sequence analysis of the genes encoding the nucleocapsid protein $(\mathrm{N})$ and phosphoprotein $(P)$ of phocid distemper virus and RNA editing a transcript of the P gene. J. Gen. Virol., 73: 885-893.

Bostock, C.J., Barrett, T. and Crowther, J.R., 1990. Characterization of the European seal morbillivirus. In: S. Edwards, and P.-P. Pastoret (Editors), Advances in Veterinary Virology. Elsevier, Amsterdam, pp. 351-360.

Carter, S.D., Hughes, D.E., Bell, S.C. and Baker, J.R., 1989. Immune response to distemper antigens during the 1988 outbreak of phocine distemper in the common seal (Phoca vitulina). Immune Biol., 23: 152-153.

Cosby, S.L., McQuaid, S., Duffy, N., Lyons, C., Rima, B.K., Allan, G.M., McCullough, S.J., Kennedy, S., Smyth, J.A., McNeilly, F. and Craig, C., 1988. Characterization of a seal morbillivirus. Nature, 336: 115-116.

Curran, M.D., O'Loan, D., Rima, B.K. and Kennedy, S., 1990. Nucleotide sequence analysis of phocine distemper virus reveals its distinctness from canine distemper virus. Vet. Rec., 127 : $430-431$.

Dietz, R., Ansen, C.T., Have, P. and Heide-Jörgensen, M.P., 1989. Clue to seal epizootic? Nature, 338: 627.

Domingo, M., Ferrer, L., Pumarola, M., Marco, A., Plana, J., Kennedy, S., McAliskey, M. and Rima, B.K., 1990. Morbillivirus in dolphins. Nature, 348: 21.

Domingo, M., Visa, J., Pumarola, M., Marco, A.I., Ferrer, L., Rabanal, R. and Kennedy, S., 1992. Pathological and immunocytochemical studies of morbillivirus infection in striped dolphins (Stenella coeruleoalba). Vet. Pathol., 29: 1-10.

Grachev, M.A., Kumarev, V.P., Mamaev, L.V., Zorin, V.L., Baranova, L.V., Denikina, N.N.. Delikov, S.I., Petrov, E.A., Kolesnik, V.S., Kolesnik, R.S., Dorofeev, V.M., Beim, A.M., Kudelin, V.N., Nagieva, F.G. and Sidorov, V.N., 1989. Distemper virus in Baikal seals. Nature, 338: 209.

Haas, L., Subbarao Shaila M., Harder, T., Liess, B. and Barrett, T., 1991. Detection of phocid distemper virus RNA in seal tissues using slot hybridization and the polymerase chain reaction amplification assay: genetic evidence that the virus is distinct from canine distemper virus. J. Gen Virol., 72: 825-832.

Harder. T., Willhaus, T., Frey, H.-R. and Liess, B., 1990. Morbillivirus infections of seals during the 1988 epidemic in the Bay of Heligoland. III. Transmission studies of cell culture-propagated phocine distemper virus in harbour seals (Phoca vitulina) and a grey seal (IIalichoerus grypus): clinical, virological and serological results. J. Vet. Med. B, 37: 641-650.

Harder, T., Moennig, V., Greiser-Wilke, I., Barrett, T. and Liess, B., 1991. Analysis of antigenic differences between sixteen phocine distemper virus isolates and other morbilliviruses. Arch. Virol., 118: 261-268.

Harder, T., Wilhaus, T., Leibold, W. and Liess, B., 1992. Investigations on course and outcome of phocine distemper virus infection in harbour seals (Phoca vitulina) exposed to polychlorinated biphenyls. Virological and serological investigations. J. Vet. Med. B, in press.

Have, P., Dietz, R. and Heide-Jörgensen, M.P., 1989. Survey of antibodies against seal distemper virus in Greenland. Abstract, Int. Workshop Current Res. Seal Disease, 20-29 February, 1989. Hannover Vet. School.

Jäger, M., Liess, B., Harder, T., Ising, S. and Stoye, M., 1990. Experimental inoculation of beagle dogs permits serological differentiation of phocine and canine distemper virus. Wien Tierärztl. Monatschr., 77: 105-108. 
Kennedy, S., Smyth, J.A., McCullough, S.J., Allan, G.M., McNeilly, F. and McQuaid, S., 1988. Confirmation of cause of recent seal deaths. Nature, 335: 404.

Kövamees, J., Blixenkrone-Møller, M., Sharma, B., Örvell, C. and Norrby, E., 1991. The nucleotide sequence and deduced amino acid composition of the haemagglutinin and fusion proteins of the morbillivirus phocid distemper virus. J. Gen. Virol., 72: 2959-2966.

Liess, B., Frey, H.-R. and Zaghawa, A.. 1989a. Morbillivirus in seals: isolation and some growth characteristics in cell culture. Disch. Tierärztl. Wochenschr., 96: 180-182.

Liess, B., Frey, H.-R., Zaghawa, A. and Stede, M., 1989b. Morbillivirus infection of seals (Phoca vitulina) during the 1988 epidemic in the Bay of Heligoland. I. Mode, frequency and significance of cultural virus isolation and neutralizing antibody detection. J. Vet. Med. B, 36: $601-608$.

Liess, B., Frey, H.-R., Willhaus, Theda and Zaghawa, A., 1989c. Morbillivirus infection among seals (Phoca vitulina) during the 1988 epidemic in the Bay of Heligoland. II. Serological investigations reflecting a previous phocine distemper epidemic in a seal orphanage. J. Vet. Med. B, 36: 709-714.

Mahy, B.W.J., Barrett, T., Evans, S.A., Anderson, E.C. and Bostock, C.J., 1988. Characterization of seal morbillivirus. Nature, 336: 115.

Örvell, C., Blixenkrone-Møller, M., Svansson, V. and Have, P., 1990. Immunological relationships between phocid and canine distemper virus studied with monoclonal antibodies. J. Gen. Virol., 71: 2085-2092.

Osterhaus, A.D.M.E. and Vedder, E.J., 1988. Identification of virus causing recent seal deaths. Nature, 335: 20.

Osterhaus, A., Groen, J., De Vries, P., UytdeHaag, F., Klingeborn, B. and Larnke, R., 1988. Canine distemper virus in seals. Nature, 335: 403-404.

Osterhaus, A.D.M.E., Groen, J., UytdeHaag, F.G.C.M., Visser, I.K.G., Van de Bildt, M.W.G. and Bergman, A., 1989. Distemper in Baikal seals. Nature, 338: 209-210.

Osterhaus, A.D.M.E., Groen, J., Spijkers, H.E.M., Broeders, H.W.J., UytdeHaag, F.G.C.M., De Vries, P., Teppema, J.S., Visser, I.K.G., Van de Bildt, M.W.G. and Vedder, E.J., 1990. Mass mortality in seals caused by a newly discovered virus-like morbillivirus. In: S. Edwards and P.-P. Pastoret (Editors), Advances in Veterinary Virology. Elsevier, Amsterdam, pp. 343350.

Osterhaus, A.D.M.E., Visser, I.K.G., De Swart, R.L., Van Bressem, M.F., Van de Bildt, M.W.G., Örvell, C., Barrett, T. and Raga, J.A., I992. Morbillivirus threat to Mediterranean monk seals? Vet. Rec., 130: 141-142.

Rima, B.K., Cosby, S.L., Duffy, N., Lyons, C., O’Loan, D., Kennedy, S., McCullough, S.J., Smyth, J.A. and McNeilly, F., 1990. Humoral immune response in seals infected by phocine distemper virus. Res. Vet. Sci., 49: 114-116.

Visser, I.K.G., Kumarev, V.P., Örvell, C. De Vries, P., Broeders, H.W.J., Van de Bildt. M.W.G., Groen, J., Teppema, J.S., Burger, M.C., UytdeHaag, F.G.C.M. and Osterhaus, A.D.M.E., 1990. Comparison of two morbilliviruses isolated from scals during outbreaks of distemper in North West Europe and Siberia. Arch. Virol., 111: 149-164.

Zaghawa, A., Liess, B. and Frey, H.-R., 1990. Antiserum raised in pigs against canine distemper virus and its utility in diagnostic procedures for morbillivirus infections (canine distemper, phocine distemper, rinderpest ). J. Vet. Med. B, 37: 353-362. 